\title{
Hanford and Oak Ridge Underground Storage Tank Waste
} Filtration Process Evaluation

by

D. J. McCabe

Westinghouse Savannah River Company

Savannah River Site

Aiken, South Carolina 29808

\section{MASTER}

DOE Contract No. DE-AC09-89SR18035

This paper was prepared in connection with work done under the above contract number with the U.S. Department of Energy. By acceptance of this paper, the publisher and/or recipient acknowledges the U. S. Government's right to retain a nonexclusive, royalty-free license in and to any copyright covering this paper, along with the right to reproduce and to authorize others to reproduce all or part of the copyrighted paper. 


\section{DISCLAIMER}

This report was prepared as an account of work sponsored by an agency of the United States Government. Neither the United States Government nor any agency thereof, nor any of their employees, makes any warranty, express or implied, or assumes any legal liability or responsibility for the accuracy, completeness, or usefulness of any information, apparatus, product, or process disclosed, or represents that its use would not infringe privately owned rights. Reference herein to any specific commercial product, process, or service by trade name, trademark, manufacturer, or otherwise does not necessarily constitute or imply its endorsement, recommendation, or favoring by the United States Government or any agency thereof. The views and opinions of authors expressed herein do not necessarily state or reflect those of the United States Government or any agency thereof.

This report has been reproduced directly from the best available copy.

Available to DOE and DOE contractors from the Office of Scientific and Technical Information, P. O. Box 62, Oak Ridge, TN 37831; prices available from (423) 576-8401.

Available to the public from the National Technical Information Service, U. S. Department of Commerce, 5285 Port Royal Road, Springfield, VA 22161. 


\section{DISCLAIMER}

Portions of this document may be illegible electronic image products. Images are produced from the best available original document. 


\title{
WSRC-TR-96-60232
}

Hanford and Oak Ridge Underground Storage Tank Waste Filtration Process Evaluation

(U)

\author{
By \\ R.A. Peterson $A 1 P$ \\ D.J. McCabe QAftise \\ Westinghouse Savaninah River Company \\ Savannah River Site \\ Aiken, SC 29808
}

\section{Summary}

Proposed treatment processes for aqueous radioactive wastes at Hanford and Oak Ridge National Laboratory (ORNL) include pretreatment to separate insoluble solids from the aqueous waste. These treatment processes include the High Level Waste at Hanford, Gunite tanks, Radiochemical Engineering Development Center, Newly Generated Low Level Liquid Waste, and the Melton Valley Storage Tank Cesium Removal at ORNL. Crossflow filtration, dead-end filtration, and settling are potential methods applicable to these separations. Crossflow filtration testing in support of three of these proposed treatment processes has been completed to aid in selection of the appropriate technique for each application.

A variety of cross flow filters were evaluated for use in processing waste streams from both Hanford and Oak Ridge. This preliminary testing was conducted using simulants developed to mimic the radioactive waste. These tests provide an early indication of the filter types that will produce the best filtration performance.

- For the concentrated ( $8.0^{\circ}$ wt \%) Hanford simulant, a 0.5 micron Mott filter produced the highest filtrate flow rate.

- For the dilute $(0.05$ wt \%) Hanford simulant, a 1.0 micron Graver filter produced the highest filtrate flow rate.

- For the $3.0 \mathrm{wt} \%$ Radiological Engineering Development Center (REDC) simulant, the 0.5 micron Mott filter produced the highest filtrate flow rate.

- For the first step of the Newly Generated Low Level Liquid Waste (NGLLLW) process, a 0.5 micron Mott filter produced the highest filtrate flowrate for the 0.02 wt \% simulant.

Furthermore, the filtration processes could be divided according to the mechanism that dominated the filtration performance.

- For the dilute Hanford simulants and the first step of the NGLLLW process, filtrate flow rate is controlled by the pressure drop across the filter due to the formation of sub-surface filter cake.

- For the concentrated Hanford-simulant and the REDC simulant, the filtrate flow rate is controlled by axial velocity across the filter due to the limited back-transport of solids from the surface of the filter.

- The filtrate quality for all filter types was comparable, and exceeds the criteria for downstream processes. 


\section{Introduction}

A number of diverse waste streams exist throughout the Department of Energy (DOE) complex. The design of processes for the treatment of these wastes are in various stages of development. ' For several of those processes in definition stage, cross flow filtration has been identified as a prospective technology. This work provides information to aid in the selection of the appropriate cross flow filtration equipment and the optimal operating conditions. In addition, analysis of this data provides information regarding the mechanism that controls cross flow. filtration for these waste streams.

Four separation processes have been identified as strong candidates for the use of cross flow filtration. Two of these applications of cross flow filtration involve processing of waste from the Hanford site. The first of the Hanford applications involves filtration of the decanted supernate from sludge leaching and washing operations. This process involves the concentration and removal of dilute fines $(0.05 \mathrm{wt} \%)$ from the bulk of the supernate. The second application involves filtration to wash and concentrate the sludge during out-oftank processing. This process employs a relatively concentrated ( $8 \mathrm{wt} \%$ solids) feed stream.

The other two applications of cross flow filtration that were tested involve waste streams from Oak Ridge National Lab (ORNL). A process for concentrating Radiochemical Engineering Development Center (REDC) waste has been developed and piloted at ORNL using a 0.5 micron Mott cross flow filter. This project investigated the use of other cross flow filters for this waste for the purpose of identifying the optimal operating conditions for a given stage of the process. A second waste treatment process is in development at ORNL for treatment of Newly Generated Low Level Liquid Waste (NGLLLW). The first stage of that process involves coprecipitation of radioactive strontium with non-radioactive strontium, followed by filtration. A goal of this work was to identify the viability of various cross flow filtration technologies and to bracket operating conditions for these processes.

The filters tested for these applications were selected based on the ability to tolerate high radiation fields. The filters used were constructed primarily of stainless steel and can be welded. These filters were among those recommended for testing of these waste streams ${ }^{1}$ and the Mott filters currently installed in the SRS In-Tank Precipitation facility.

\section{Experimental}

Simulants were developed at Pacific Northwest Laboratory (PNL) ${ }^{2}$ and $\mathrm{ORNL}^{3}$ for testing of the cross flow filtration processes. These simulants were prepared following the instructions prepared at the other sites without modification except where noted. The compositions of these simulants are shown in Table 1 through Table 4. The S-103 and S-3 simulants represent Hanford waste. Simulant $S-103$ was developed to accurately reflect the chemical composition of the Hanford waste, in particular Tank C-103, while S-3 was developed to accurately reflect the physical properties, in particular the particle size, of the Tank C-103 Hanford waste. The simulant that contained $0.05 \mathrm{wt} \%$ insoluble solids represents supernate from the settled sludge while the $8.0 \mathrm{wt} \%$ simulant represents unwashed retrieved sludge. Single composition simulants were employed in studies of both REDC and NGLLLW processes (Tables 3 and 4). These simulants are based on the best available information to represent both the chemical and physical properties of the actual waste. 
Table-1. Composition of Slurry S-3 (basis 10 liters)

\begin{tabular}{|c|c|c|}
\hline $\begin{array}{l}\text { Component } \\
\text { Boehmite }\end{array}$ & $\begin{array}{l}\mathrm{S}-38.0 \mathrm{wt} \% \\
(\text { mass, g) } \\
785.8\end{array}$ & $\begin{array}{l}\text { S-3 } 0.05 \text { wt \% } \\
\quad \text { (mass, g) } \\
4.5\end{array}$ \\
\hline $\begin{array}{l}\text { (Vista catapal D) } \\
\text { Gibbsite } \\
\text { (SpaceRite S-3) }\end{array}$ & 174.6 & 0.5 \\
\hline $\mathrm{NaOH}$ & 40 & 40 \\
\hline
\end{tabular}

Table 2. Composition of Slurry S-103 (basis 10 liters)

\begin{tabular}{|lcrrr|}
\hline Component & $\begin{array}{c}\text { S-103 8.0 wt \% } \\
\text { (mass, g) }\end{array}$ & $\begin{array}{c}\mathrm{S}-1030.05 \text { wt \% } \\
\text { (mass, g) }\end{array}$ & $\begin{array}{c}\text { S-103m 8.0 wt \% } \\
\text { (mass, g) }\end{array}$ & $\begin{array}{c}\text { S-103m 0.05 wt \% } \\
\text { (mass, g) }\end{array}$ \\
Fe(NO3)3.9H2O & 1225 & 7.65 & -.1225 & 7.65 \\
NaNO3 & - & - & 3477 & 1998 \\
5 M NaOH & 364 & 2.3 & 364 & 2.3 \\
Colloidal Silica & 651 & 4.05 & 651 & 4.05 \\
Alumina (S-11) & 70.6 & 0.45 & 70.6 & 0.45 \\
Boehmite alumina & 21.7 & 0.15 & 21.7 & 0.15 \\
Calcium tri basic & 130.3 & 0.8 & 130.3 & 0.8 \\
\hline
\end{tabular}

$\mathrm{S}-103 \mathrm{~m}$ is a modification of slurry S-103 with a sodium molarity of $5 \mathrm{M}$.

Table 3. NGLLLW Composition (basis 20 liter)

\begin{tabular}{|ll|}
\hline \multicolumn{1}{|c|}{ Component } & Amount \\
$\mathrm{NaNO}_{3}$ & 101.7 \\
$\mathrm{NaCl}$ & 41.1 \\
$\mathrm{LiCl}$ & 21.2 \\
$\mathrm{NaAlO}$ & \\
$\mathrm{NaOH}$ & 19.2 \\
$\mathrm{Na}_{2} \mathrm{CO}_{3} \cdot \mathrm{H}_{2} \mathrm{O}$ & 100 \\
$\left.\mathrm{Sr}^{\mathrm{NO}}\right)_{2}$ & 248.1 \\
$\mathrm{Fe}_{2}\left(\mathrm{SO}_{4}\right)_{3} \cdot 9 \mathrm{H}_{2} \mathrm{O}$ & 2.42 \\
\hline
\end{tabular}

Table 4. REDC composition (basis 10 liters)

\begin{tabular}{|ll|}
\hline Component & Amount \\
(grams) \\
$\mathrm{AlNO}_{3}$ & 480 \\
$\mathrm{FeNO}$ & 380 \\
$\mathrm{ZrONO}$ & 362 \\
$\mathrm{Sr}\left(\mathrm{NO}_{3}\right)_{2} \cdot$ & - \\
$\mathrm{Eu}\left(\mathrm{NO}_{3}\right)_{3} \cdot 5 \mathrm{H}_{2} \mathrm{O}$ & 0.217 \\
$\mathrm{Gd}\left(\mathrm{NO}_{3}\right)_{3} \cdot 6 \mathrm{H}_{2} \mathrm{O}$ & 0.282 \\
$\mathrm{NaOH}$ & 0.287 \\
\hline
\end{tabular}

Particle size distribution data were collected on the simulated waste samples. The samples were analyzed using a Microtrac II, Series 7998 Particle Size Analyzer. The range of this instrument is 0.7 to 700 microns. The instrument operates via low-angle forward scattering of diode laser light. The samples were constantly mixed with a stirrer. All sludge samples were analyzed by dilution in filtrate by passing through a 0.45 micron filter and verifying the absence of solids with the analyzer. The samples were analyzed immediately after introduction to the instrument and again after stirring for 20 minutes in the instrument. Three columns of data are presented in Table 5; the particle diameter below which 10,50 , and 90 volume percent of the particles lie. Inspection of this data indicates that agglomeration occurs for the S-103 8.0 wt \% simulant and for the S3 0.05 wt \% simulant. All other simulants have a mean particle siże between 2.4 and 5.7 microns. 
page 4 of 18

WSRC-TR-96-0232

Table 5. Particle Size Data

\begin{tabular}{|l|l|l|l|l|}
\hline \multirow{2}{*}{ Simulant } & Time & $\begin{array}{l}10 \% \\
\text { (microns) }\end{array}$ & $\begin{array}{l}50 \% \\
\text { (microns) }\end{array}$ & $\begin{array}{l}90 \% \\
\text { (microns) }\end{array}$ \\
\hline S-103 0.05wt\% & $0 \mathrm{~min}$ & 2.36 & 47.64 & 85.99 \\
\cline { 2 - 5 } & $20 \mathrm{~min}$ & 20.17 & 55.92 & 88.31 \\
\hline S-103 8.0 wt\% & $0 \mathrm{~min}$ & 20.40 & 52.60 & 78.79 \\
\cline { 2 - 5 } & $20 \mathrm{~min}$ & 1.10 & 2.70 & 8.01 \\
\cline { 2 - 5 } & $115 \mathrm{~min}$ & 1.12 & 2.79 & 7.26 \\
\hline \multirow{3}{*}{ S3 0.05 wt\% } & $0 \mathrm{~min}$ & 1.21 & 4.46 & 351.9 \\
\cline { 2 - 5 } & $20 \mathrm{~min}$ & 0.95 & 1.91 & 4.25 \\
\hline S3 8.0 wt \% & $0 \mathrm{~min}$ & 1.13 & 2.41 & 4.35 \\
\cline { 2 - 5 } & $20 \mathrm{~min}$ & 1.13 & 2.39 & 4.26 \\
\hline \multirow{3}{*}{ S-1038.0 wt\% } & $0 \mathrm{~min}$ & 1.35 & 7.16 & 100.59 \\
\cline { 2 - 5 } & $20 \mathrm{~min}$ & 1.07 & 2.50 & 8.55 \\
\hline S103m 8.0 wt\% & $0 \mathrm{~min}$ & 1.24 & 3.42 & 12.64 \\
\cline { 2 - 5 } & $20 \mathrm{~min}$ & 1.25 & 3.96 & 13.24 \\
\hline NGLLLW & $0 \mathrm{~min}$ & 2.32 & 6.33 & 15.84 \\
\cline { 2 - 5 } & $20 \mathrm{~min}$ & 2.11 & 5.33 & 11.54 \\
\hline REDC & $0 \mathrm{~min}$ & 1.35 & 3.56 & 10.23 \\
\cline { 2 - 5 } & $20 \mathrm{~min}$ & 1.29 & 4.04 & 10.04 \\
\hline
\end{tabular}

The sample of S3-0.05 did not contain a sufficient quantity of solids to perform the particle size analysis. It should also be noted that bubbles may interfere with some of these analyses. Foaming was commonly observed during the first few minutes in the particle size analyzer. The presence of foam indicates that bubbles may be present in the solution, although this cannot be confirmed.

Cross flow filtration experiments were performed with each of these simulants using the Experimental Lab Filter (ELF) unit shown in Figure 1. Each test involved measuring the filtrate flux under a variety of conditions. The two independent variables for these tests were pressure drop and axial velocity. The conditions for these tests are listed in Table 6. A backpulse was performed following each change in the test parameters except for the Microfiltrex filter. Measurements were taken at each test condition for a period of 1 hour. For each simulant, tests were performed with a number of cross flow filters: A summary of the filters employed in testing each simulant is listed in Table 7. Following the completion of each test, a statistical analysis determined the dependence of filtrate flux for those test conditions as a function of pressure drop and axial velocity. An additional analysis was performed to determine the dependence of filter performance on time (as an indication of filter fouling). 
Table 6 Test settings.

\begin{tabular}{|ccc|}
\hline Setting Number & $\begin{array}{c}\text { Pressure } \\
\text { (psi) } \\
1\end{array}$ & $\begin{array}{c}\text { Velocity } \\
(\mathrm{ft} / \mathrm{s})\end{array}$ \\
2 & 39 & 8 \\
3 & 29 & 10.8 \\
4 & 14 & 2.6 \\
5 & 19 & 8 \\
6 & 29 & 10.8 \\
7 & 39 & 8 \\
8 & 44 & 5.3 \\
9 & 29 & 13.5 \\
10 & 19 & 5.3 \\
11 & 29 & 8 \\
12 & 29 & 4.3 \\
13 & 29 & 6 \\
14 & 29 & 9.6 \\
15 & 29 & 11.3 \\
16 & 29 & 8 \\
17 & 39 & 8 \\
18 & 34 & 8 \\
19 & 24 & 8 \\
20 & 19 & 8 \\
21 & 29 & 8 \\
\hline
\end{tabular}

Upon conclusion of each filter test, a cleaning step was employed. During this step, all the slurry was removed from the process vessel and process lines. These lines were then flushed three times in a once through pass. The process vessel was then filled with inhibited ( $\mathrm{pH} \mathrm{10)}$ water that was recirculated for a period of 1 hour with periodic backpulses. Following this, the process vessel was again drained and refilled with 0.5 wt\% oxalic acid. The oxalic acid solution was then circulated through the process loop for 60 minutes with periodic backpulses. Following 2 additional flushes with inhibited water, this process was repeated with a $0.01 \mathrm{M} \mathrm{NaOH}$ solution with periodic backpulses. Finally, a measurement of the clean water flux was made. This process was found to be sufficient for all filter tests with the exception of those employing the Microfiltrex filter. In this case, repeated cleanings were required. Note that backpulses were not performed during the cleaning process for the Microfiltrex filter.

As indicated in Table 7, a number of filters were employed during these tests. The Mott and Graver filters were fabricated by sintering 316 stainless steel particles and are seamless tubes. Pore size is controlled by the size of the primary particles and the sintering conditions. The Mott filters were 0.0625 inches thick. The Microfiltrex filters are a thinwalled sintered metal filter and are not backpulsed. The Vacco filter is composed of compressed stacked etched disks. All these filter represent a wide variety of pore sizes. The filters with larger pore sizes are expected to produce higher initial fluxes but are more susceptible to fouling. 


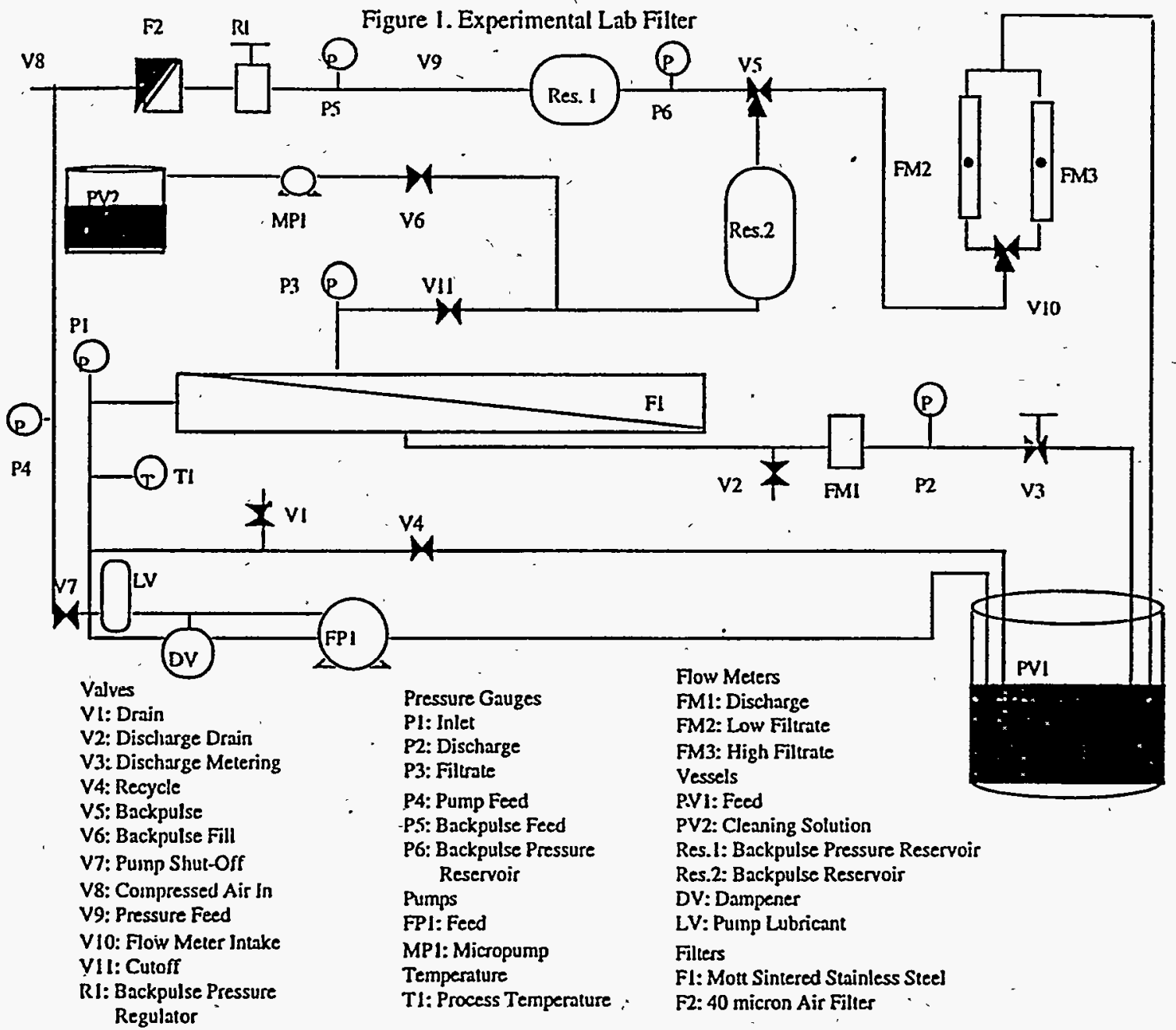

Table 7. Filters employed for various tests with specified simulants.

\begin{tabular}{|c|c|c|c|c|c|}
\hline Simulant & $\begin{array}{l}\text { Vacco } \\
3.7 \mu\end{array}$ & $\begin{array}{c}\text { MicrofiltreX } \\
1.0 \mu\end{array}$ & $\begin{array}{c}\text { Mott } \\
2.0 \mu\end{array}$ & $\begin{array}{c}\text { Mott } \\
0.5 \mu\end{array}$ & $\begin{array}{c}\text { Graver } \\
1.0 \mu\end{array}$ \\
\hline $\begin{array}{c}\text { S-103 } \\
(8.0 \mathrm{wt} \%)\end{array}$ & $\mathrm{X}$ & $\mathrm{X}$ & $\mathrm{X}$ & $\mathrm{X}$ & $\mathrm{X}$ \\
\hline $\begin{array}{c}\text { S-103m } \\
(8.0 \mathrm{wt} \%)\end{array}$ & & & & $\mathrm{X}$ & $\cdot$ \\
\hline $\begin{array}{c}\text { S-103 } \\
(0.05 \mathrm{wt} \%)\end{array}$ & & $\mathrm{X}$ & $\mathrm{X}$ & $\mathrm{X}$ & $\mathrm{X}$ \\
\hline $\begin{array}{c}\text { S-3 } \\
(8.0 \mathrm{wt} \%)\end{array}$ & & & & $\mathrm{X}$ & \\
\hline $\begin{array}{c}\text { S-3 } \\
(0.05 \mathrm{wt} \%)\end{array}$ & - & & & & $\mathrm{X}$ \\
\hline $\begin{array}{c}\text { REDC } \\
(3.0 \mathrm{wt} \%)\end{array}$ & $\mathrm{X}$ & & & $\mathrm{X}$ & $\mathrm{X}$ \\
\hline $\begin{array}{c}\text { NGLLLW } \\
(0.02 \mathrm{wt} \%)\end{array}$ & & & & $\mathrm{X}$ & $\mathrm{X}$ \\
\hline
\end{tabular}


The smaller pore size filters are expected to produce lower initial fluxes but be more resistant to fouling. Results from the Vacco filter do not completely agree with this assumption due to the unique method of manufacture. This filter is not expected to foul to as great an extent but is also expected to have a slightly lower initial filtrate flow rate due to the low porosity. On the basis of pore size, the Graver would be expected to perform similarly to the Mott filters. However, there are significant differences in the methods of manufacture and the Graver filter appears to perform similar to a filter with a smaller pore size.

An M2 Wilden Diaphragm pump provided slurry flow: Prior to each test, the clean water flux was measured to ensure the filter had been returned to a clean state.

\section{Filtration Mechanism}

Cross flow filtration can be separated into two areas of operation. In the first area of operation, the axial velocity is sufficient to remove any solids from the surface of the filter. Thus, there is not an accumulation up of filter cake on the surface of the filter and any decrease in filter performance is attributed to the deposition of solids within the filter subsurface. This area of operation is usually associated with dilute feed streams, high axial velocities and, low pressure drops. Under these conditions, increasing the axial velocity or the feed stream concentration will have little impact on filtrate production rates. 'However, increases in pressure will produce significant increases in filtrate flow rates.

When more concentrated feed streams are employed, a higher axial velocity is needed to keep the surface of the filter free of deposited solids. If the axial velocity is not sufficient, a cake of solids will deposit on the surface of the filter. The surface filter cake will cause a decrease in filter performance. Under these conditions, an increase in the axial velocity will increase the rate of transport of solids from the surface of the filter, and thus decrease the thickness of the filter cake, producing an increase in filter performance. However, an increase in pressure without increasing the axial velocity will only produce a thicker or more compressed cake and will not yield any further increase in filter performance. Thus, the first regime of operation is dominated by the operating pressure while the second regime is dominated by the axial velocity. A transition exists between these two regimes wherein an increase in either pressure or axial velocity produces an improvement in filter performance. For both dilute and concentrated solids, optimal performance is achieved with an axial velocity-operating pressure pair just above the transition region. Operation under these conditions maximizes filtrate production while utilizing the minimum amount of pump energy. A more complete discussion of filtration mechanisms is currently being prepared and will provide a more detailed explanation of the filtration mechanisms. ${ }^{4}$

\section{Filtration Results}

\section{Hanford Simulants}

Twelve tests were performed with Hanford simulants. Most of these tests produced reasonable filtrate flow rates. However, some of the tests produced very low flow rates and a statistical analysis of these data could not be completed. These tests are outlined below.

For the 8 wt \% S-103 simulant, tests with both the Vacco filter and the Graver filter gave very low flow. The test with the Microfiltrex filter gave initially high flux that decayed rapidly. Due to mechanical limitations associated with the Microfiltrex filters they could not 
be backpulsed, and it was not possible to rèstore this flux to a reasonable value without performing a chemical cleaning.

A number of tests with the $0.05 \mathrm{wt} \% \mathrm{~S}-103$ simulant also produced low flow rates. The 2.0 micron Mott filter gave very low flow that can be attributed to extensive subsurface fouling. The larger pore size of this filter causes the filter to be more susceptible to this type of fouling. Tests with the Microfiltrex filter again gave initially high flux that decayed rapidly. In addition, both these tests were characterized by relatively high turbidities in the filtrate. These samples produced turbidity measurements of greater than 20 NTU while all other filters provided filtrate characterized by turbidities of less than 5 NTU. This result is consistent with the assumption that these two filters were subject to extensive subsurface fouling.

Prior to testing, the $8 \mathrm{wt} \%$ S-3 simulant settled extensively. This simulant contained primarily boehmite alumina (see Table 1). After filtration testing, the 8 wt \% S-3 simulant did not settle. Furthermore, filtrate flow rate for this filtration test was very low. These results indicate that the particles experienced large amounts of shear and were degraded during the process of testing, causing low flow rates. This result indicates that the particles in the S-3 simulant can be extremely sensitive to shear forces.

The results of the remaining experiments (of Table 7) with Hanford simulants are shown in Figures 2 through 4 . Figure 2 contains a plot of the filtrate flux for $8 \mathrm{wt} \%$ simulant S-103 as a function of axial velocity for two filters. Statistical analysis of these data indicate that the filtrate flux is highly dependent on axial velocity, indicating that back transport of material from the surface of the filter cake is dictating filtrate flux. From the statistical analysis, a simple quadratic or linear model was developed for this data (The quadratic form was only used when the second term was found to be statistically significant). Note that these predictions are valid only over the range of operating conditions outlined in Table 6. For these two experiments, the model predicts the following dependence of filtrate flux on axial velocity

$\mathrm{Q}_{8-0.5}=0.0131 * \mathrm{~V}-0.0411$

$\mathrm{Q}_{8 \cdot 2.0}=0.0105 * \mathrm{~V}-0.0269$

where $\mathrm{Q}_{8.0 .5}$ is the filtrate flux for the 0.5 micron filter in $\mathrm{gpm} / \mathrm{sq} \mathrm{ft}, \mathrm{Q}_{8.20}$ is the filtrate flux for the 2.0 micron filter in $\mathrm{gpm} / \mathrm{sq} \mathrm{ft}$ and $\mathrm{V}$ is the axial velocity in $\mathrm{ft} / \mathrm{s}$. This result indicates that higher overall filtrate fluxes are obtained using the 0.5 micron filter. The increased viscosity of the aqueous phase for simulant S-103m did not appear to impact the filter flux.

Figure 4 contains a plot of the filtrate flux for $0.05 \mathrm{wt} \%$ simulant S- 103 as a function of pressure drop for the Mott and Graver filters. Also included for reference is a plot of the filtrate flux for $0.05 \mathrm{wt} \%$ simulant S-3 for the Graver filters. The analysis of this data indicates that filtrate flux is primarily dependent on pressure drop. The data indicate that the axial velocity is sufficient to keep the surface free of filter cake. The models for these two system are

$\mathrm{Q}_{\text {s-0.5 }}=0.00458 * \mathrm{P}+0.00639$

$\mathrm{Q}_{5-\mathrm{gr}}=0.0125 * \mathrm{P}-7.4 \times 10^{-4} * \mathrm{P}^{2}-0.085$

where $Q_{s-0.5}$ is the filtrate flux for the 0.5 micron Mott filter in $\mathrm{gpm} / \mathrm{sq} \mathrm{ft}$ and where $\mathrm{Q}_{\mathrm{s-gr}}$ is the filtrate flux for the Graver filter in $\mathrm{gpm} / \mathrm{sq} \mathrm{ft}$ and $\mathrm{P}$ is pressure in psi. These results indicate that the highest filtrate flux is achieved with the Graver filter. Comparison of the S- 103 and S-3 simulants indicates that the filtrate flux achieved with the S-103 simulant is significantly higher than that achieved with the S-3 simulant. This result is consistent with that expected based on particle size analysis of these materials. 
Figure 2. Filtrate flux for $8.0 \mathrm{wt} \% \mathrm{~S}-103$ as a function of axial velocity and filtęr type

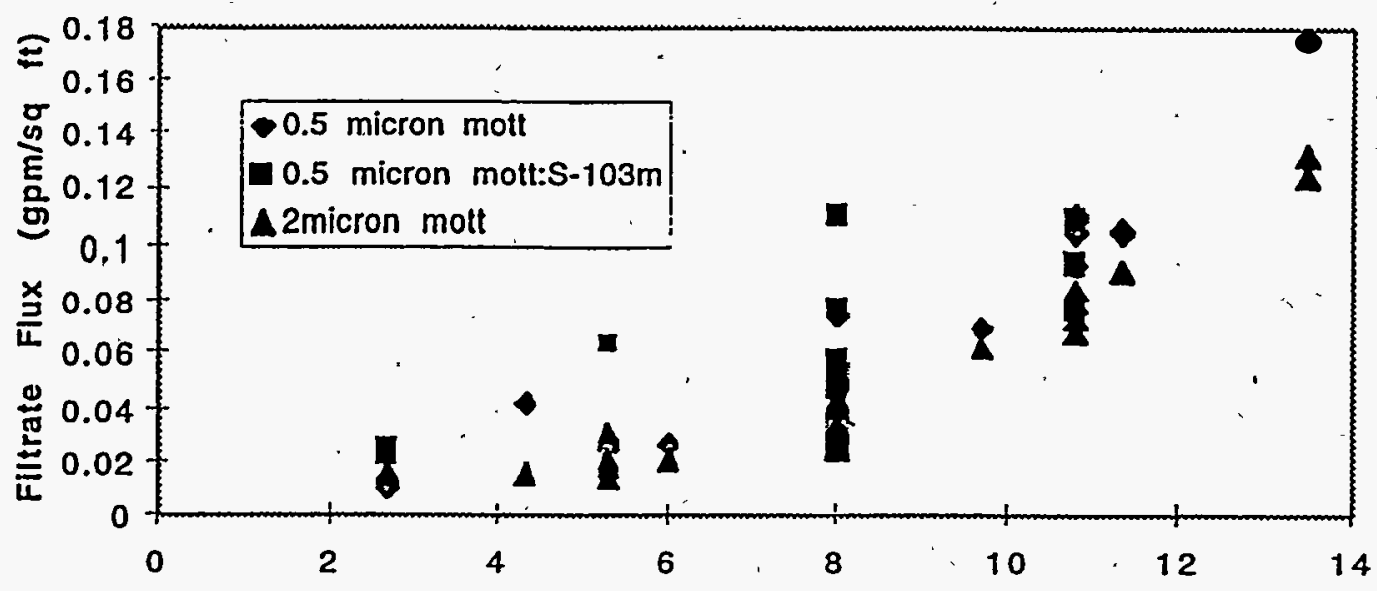

Figure 3. Filtrate flux for 8.0 wt $\%$ S-103 as a function of pressure drop velocity and filter type

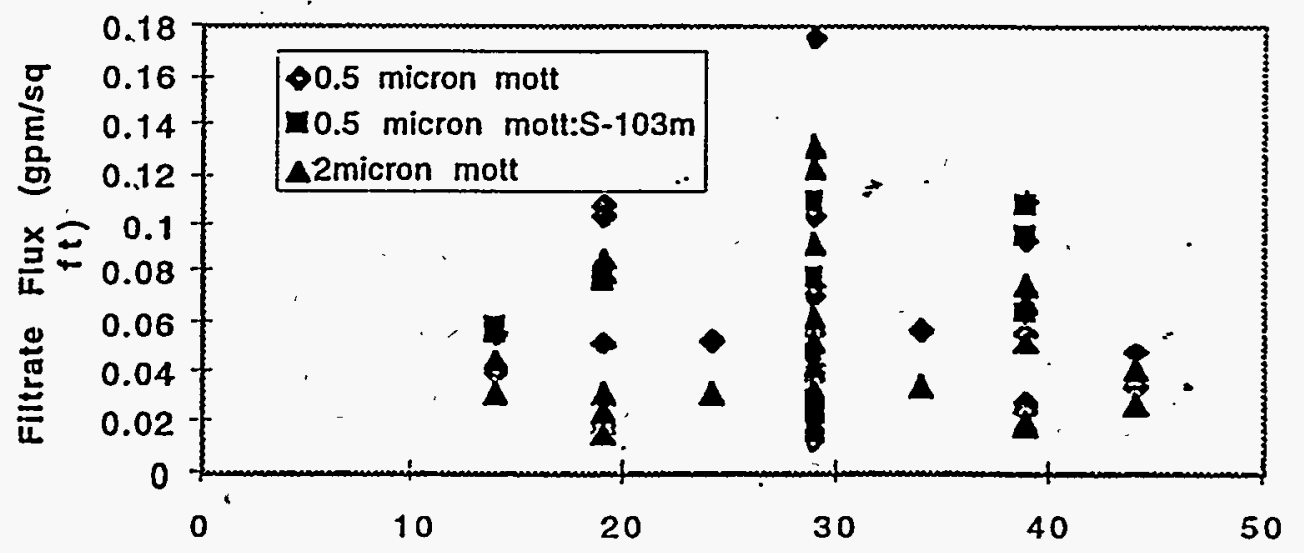


Figure 4. Filtrate flux for $0.05 w t \%$ as a function of pressure drop and filter type

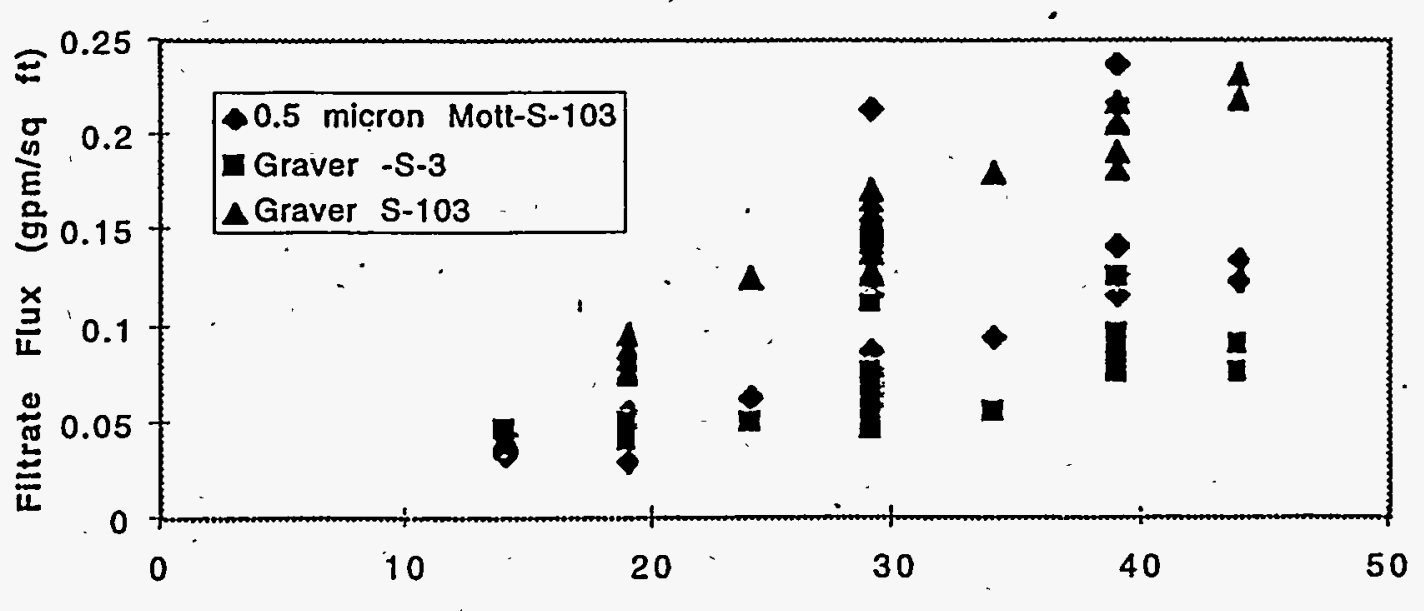

Figure 5. Filtrate flux for 0.05 , wt $\%$ as a function of axial velocity and filter type

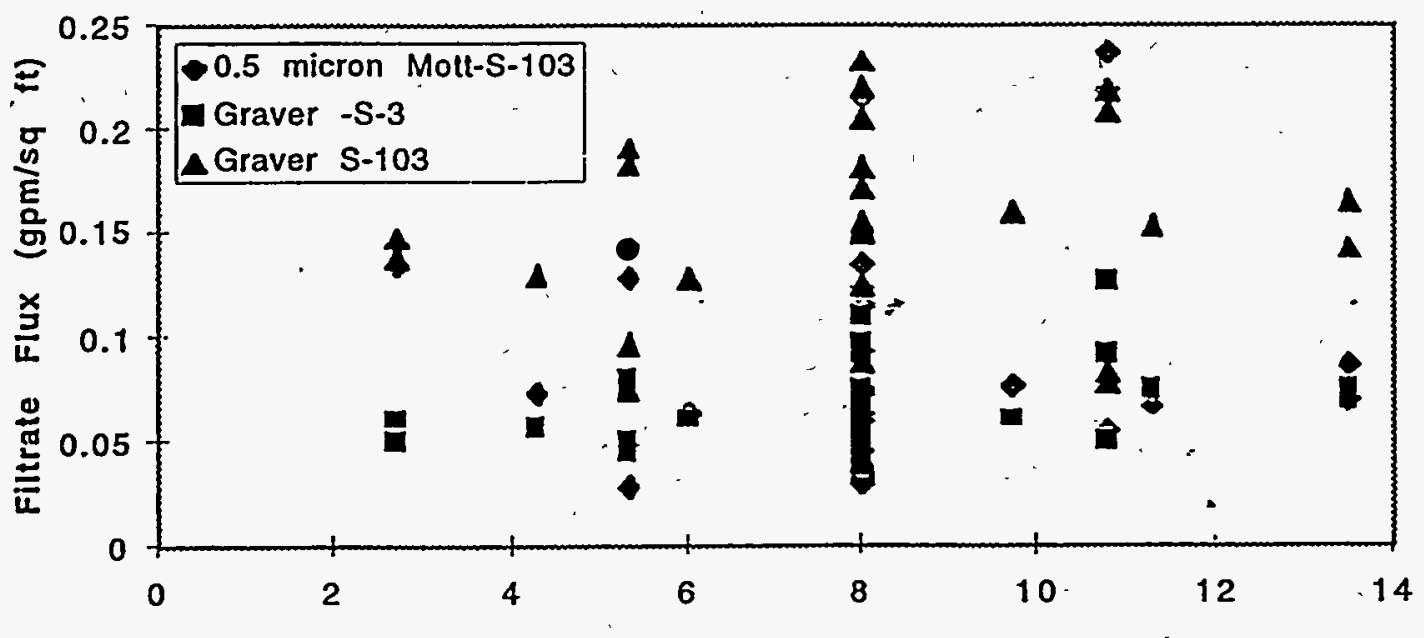

These results indicate that for the dilute Hanford waste stream, a Graver filter will produce the highest filtrate flux and that filtrate flux is dependent primarily on pressure drop. For the more concentrated Hanford waste stream, the 0.5 micron Mott filter performed the best. Furthermore, a significant filter cake has developed under these conditions and filtrate flux is determined primarily by back transport. In addition, changes in simulant composition were found to have significant impact on filter performance. In general, the changes in settling properties for the S-3 simulant indicate that this simulant was more susceptible to degradation during the duration of the experiments. Extended operating time, within the duration tested, was not found to significantly alter filtrate flux except where noted. 


\section{ORNL REDC}

As indicated in Table 7, three separate tests were performed using Radiological Engineering Development Center (REDC) simulant. These tests involved the 0.5 micron Mott filter, the 1.0 micron Graver filter and a 3.7 micron Vacco filter. All of the tests employed a 3.0 wt $\%$ REDC simulant. Figure 6 contains a plot of the filtrate flux for REDC simulant for each of these filters as a function of axial velocity. Inspection of this figure indicates that for each test, filtrate flux increased substantially with axial velocity. This result indicates that under these conditions, a significant filter cake is forming and filtration performance can be improved by operating at higher axial velocities. This plot also indicates that the maximum filtrate flux is produced by the Mott filter. The statistically developed linear models for the systems are:

$$
\begin{aligned}
& Q_{\text {REDC.Vo }}=0.00528 * \mathrm{~V}+0.117 \\
& Q_{\text {REDC.gr }}=0.0222 * \mathrm{~V}-0.063 \\
& Q_{\text {REDC.mt }}=0.061 * \mathrm{~V}-0.0024 * \mathrm{~V}^{2}-0.0101 .
\end{aligned}
$$

where $Q_{\text {REDC.V }}$ is the filtrate flux for the Vacco filter in $\mathrm{gpm} / \mathrm{sqft}, \mathrm{Q}_{\mathrm{REDC} \text {-gr }}$ is the filtrate flux for the Graver filter in $\mathrm{gpm} / \mathrm{sq} \mathrm{ft}, \mathrm{Q}_{\mathrm{REDC} \text {-nx }}$ is the filtrate flux for the Mott filter in $\mathrm{gpm} / \mathrm{sq} \mathrm{ft}$ and $\mathrm{V}$ is axial velocity in $\mathrm{ft} / \mathrm{s}$. These results indicate that higher fluxes will be achieved by increasing the axial velocity. However, the REDC filtration process starts at a lower solids concentration. Additional testing would be required to determine the optimal operating conditions for the entire REDC operating cycle.

During testing of the REDC simulant with the Mott 0.5 micron filter, strontium, gadolinium and europium nitrates were added to the simulant. These cations precipitate as the hydroxide or carbonate salts in these simulants. These samples were analyzed using a Plasma Quad II Inductively Coupled Plasma Mass Spectometer (ICPMS). These results indicated that the feed stream contained approximately $10 \mathrm{ppm}$ of each component $\left(\mathrm{Sr}^{+2}\right.$, $\mathrm{Gd}^{+3}$, and $\left.\mathrm{Eu}^{+3}\right)$. However, the filtrate was found to contain no detectable concentration of these components $(<1 \mathrm{ppb}, \mathrm{DF}>10,000)$. Extended exposure time was not found to significantly alter filtrate flux. 
Figure 6. Filtrate Flux for 3.0 wt\% REDC simulant as a function of axial velocity and filter type

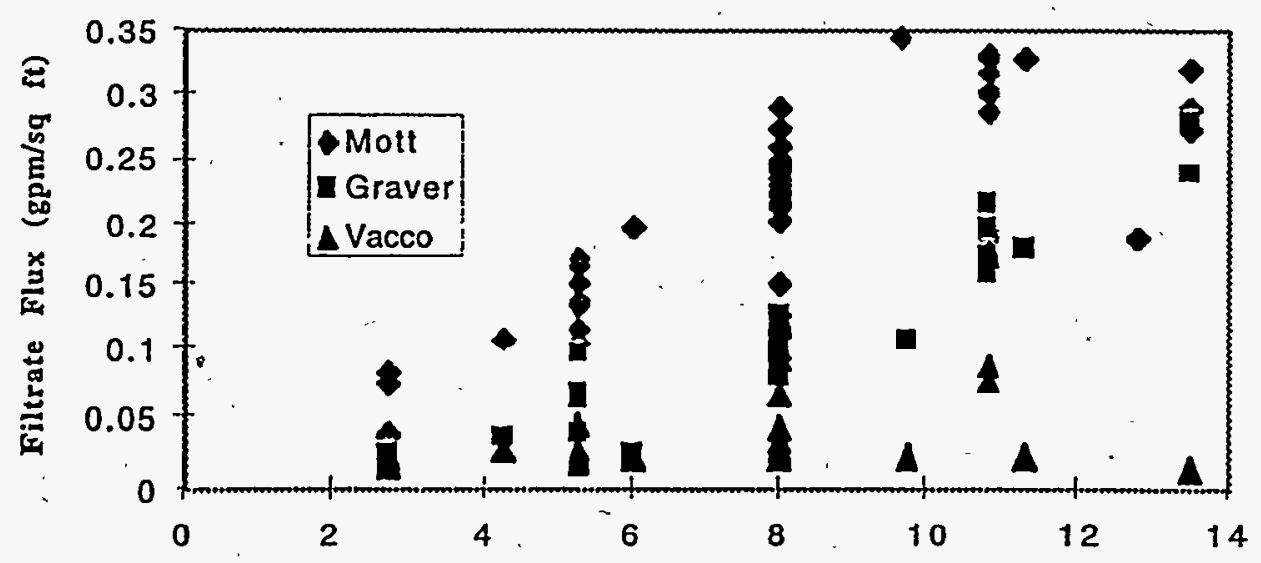

Figure 7. Filtrate Flux for 3.0 wt\% REDC simulant as a function of axial velocity and filter type

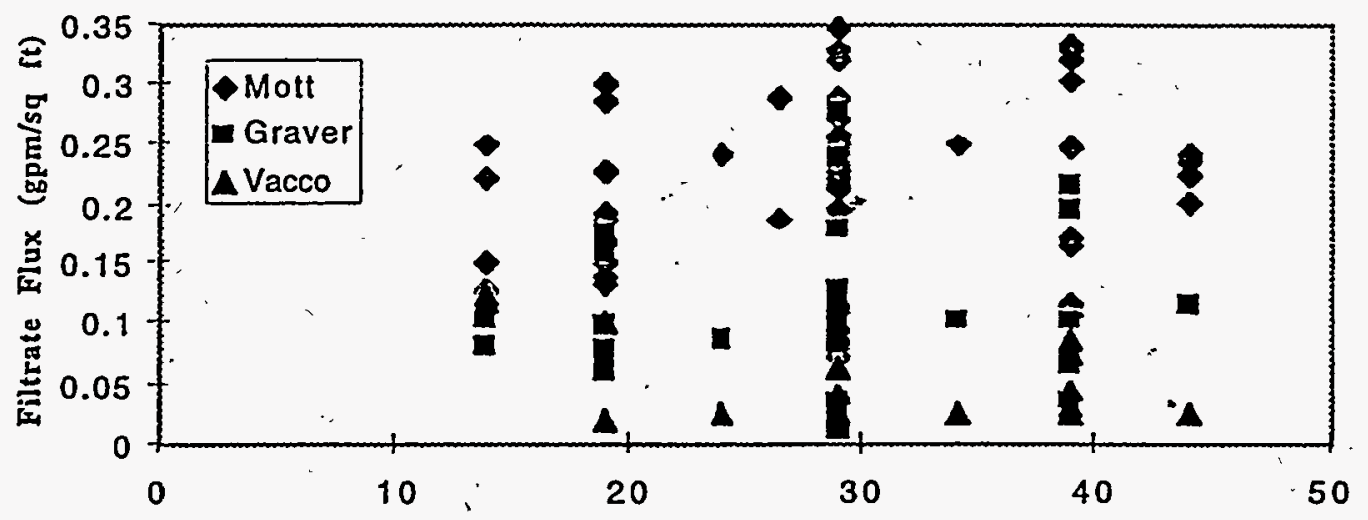

\section{ORNL NGLLLW}

Two tests were performed using the Newly Generated Low Level Liquid Waste (NGLLLW) simulant (step 1). The filters employed in these tests were a 0.5 micron Mott filter and a Graver filter. The NGLLLW (step 1) is a relatively dilute solution formed by the precipitation of iron and strontium. Figure 8 contains a plot of the filtrate flux for the two filters employed in these tests'as a function of pressure drop. Inspection of this figure indicates that the Mott filter provides the higher flux. This can be attributed to the dilute 
solids concentration and lack of foulants in the slurry. The filtrate flux produced by the Mott filter approaches the flow rate achieved with the Graver filter for clean water. Thus, there is not sufficient material present to form even a significant sub-surface cake to produce a large decrease in performance for the Mott filter. The predictions developed for these filter are:

$\mathrm{Q}_{\mathrm{NG}-\mathrm{mt}}=0.031 * \mathrm{P}-3.4 \times 10^{-4} * \mathrm{P}^{2}+0.012$

$Q_{\text {NG-GR }}=0.026 * P-3.9 \times 10^{-4} * P^{2}-0.030$.

where $Q_{N G-m i}$ is the filtrate flux for the Mott filter in gpm/sq ft, $Q_{N G-G R}$ is the filtrate flux for the Graver filter in $\mathrm{gpm} / \mathrm{sq} \mathrm{ft}$ and $\mathrm{P}$ is the pressure in psi.

These tests represent the start of processing of NGLLLW. During cross flow filtration, the concentration of the feed stream will increase. If the concentration increases sufficiently, a surfáce cake may begin to form and sufficient decrease in filtration performance may be observed to warrant the use of an alternate filter technology. Additional testing is needed to examine the range of concentrations of solids that will be observed in the process.

During testing of the NGLLLW simulant with the Mott 0.5 micron filter, strontium was added to the simulant. These samples were analyzed using a Plasma Quad II Inductively Coupled Plasma Mass Spectometer (ICPMS). The strontium concentration in the filtrate as a function of time after the backpulse is presented in Table 8 as well as the concentration of strontium in the feed solution. Inspection of this data indicates that a decontamination factor for strontium of about 400 has been obtained. Since the $\mathrm{Sr}$ does not increase after each backpulse, the filter pore size is sufficiently small to reject Sr containing solids from a clean filter surface for this application. Extended operating time was not found to significantly alter filtrate flux.

$\begin{array}{llll}\text { Sample } & \text { Time } & \text { Average }(\mathrm{ppb}) & \text { Standard Deviation (ppb) } \\ \text { Filtrate } & 0 & 120 & 7.7 \\ \text { Filtrate } & 5 & 122 & 6.9 \\ \text { Filtrate } & 15 & 125 & 8.9 \\ \text { Filtrate } & . & 124 & 11.0 \\ \text { Feed } & 30 & 51400 & 1133\end{array}$


Figure 8. Filtrate flux for NGLLLW as a function of pressure drop for Step 1 in Proposed Process

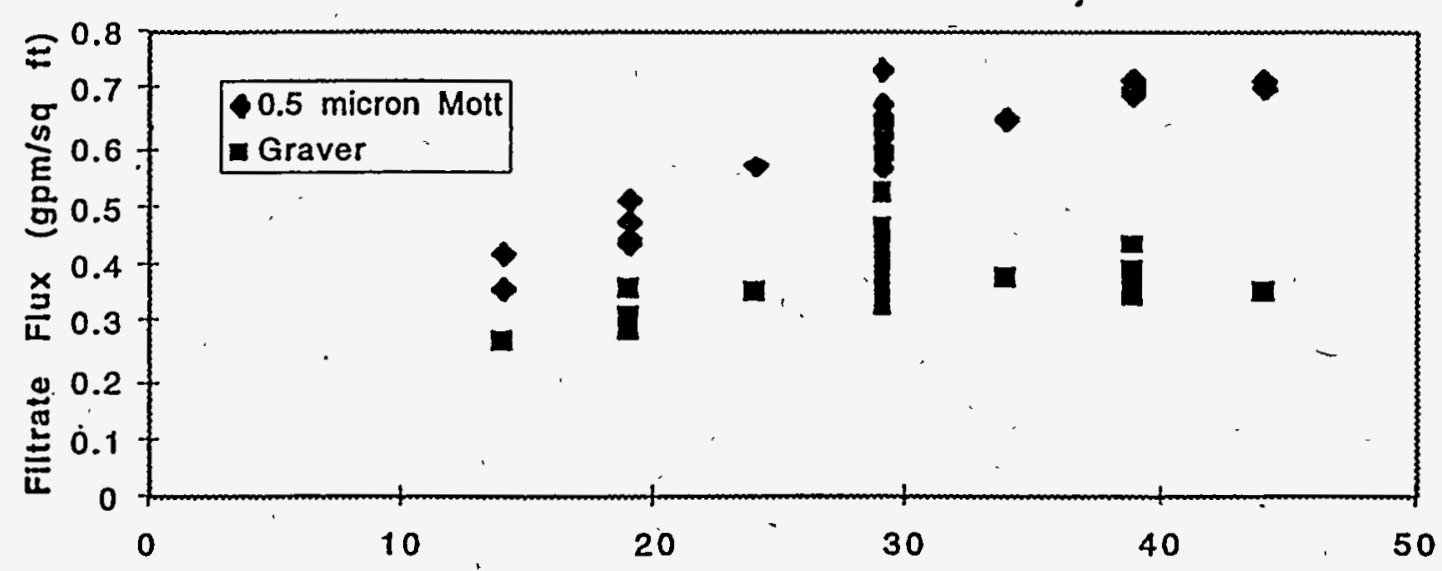

Figure 9. Filtrate flux for NGLLLW as a function of axial velocity for Step 1 in Proposed Process.

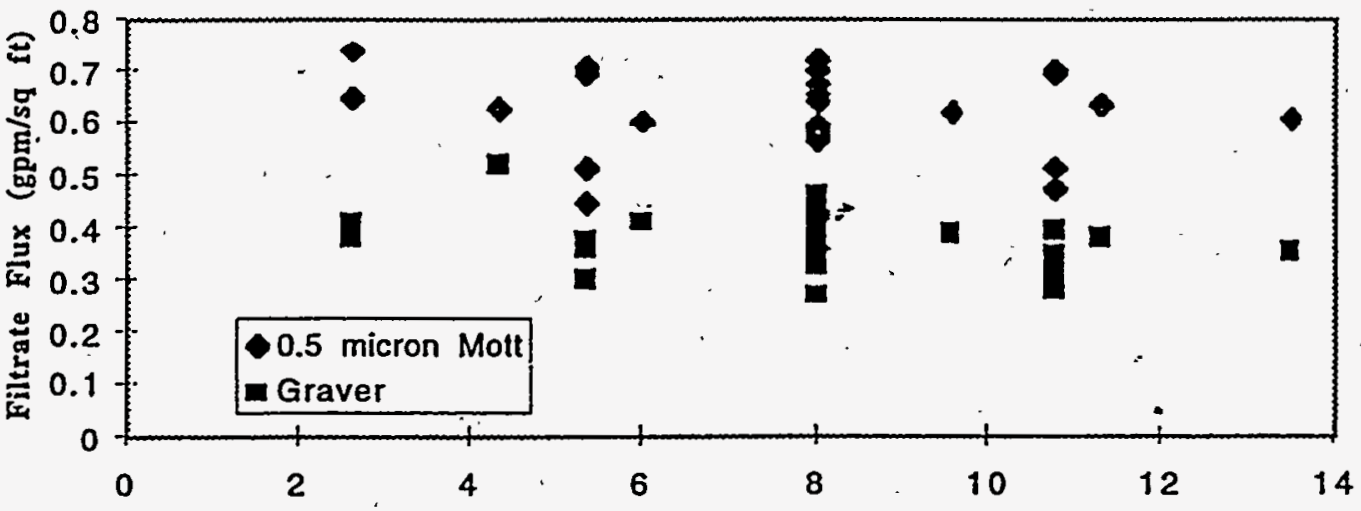

\section{Conclusions}

Tests were performed using simulants representing three of wastes for Hanford and Oak Ridge. Comparisons were made of the performance of a variety of commercially available filters. This comparison indicates that for concentrated streams ( $8 \mathrm{wt} \%$ Hanford simulants and 3 wt \% REDC simulants), a 0.5 micron Mott filter provides the best performance. For more dilute streams (i.e., the $0.05 \mathrm{wt} \%$ Hanford and NGLLLW simulants), the 1.0 micron Graver filter and 0.5 micron Mott filter provided the best performance for the 
Hanford and Oak Ridge wastes, respectively. Also, the mechanism that controls filtrate flow rate was found to change as the solids loading in the simulants changed from a subsurface cake dominated performance for dilute slurries to a back-transport dominated performance for more concentrated slurries. Also, Hanford simulants that contained primarily boehmite alumina particles were found to severely degrade during filtration operation.

\section{Future Work}

This work has been completed using small scale filtration equipment. However, there exists a need to demonstrate these filtration processes on a larger scale. Filtration for the REDC process on a larger scale has been completed by workers at ORNL using larger scale equipment. Furthermore, the NGLLLW process development is currently suspended. Thus, the most attractive process for demonstration on a larger scale is filtration of Hanford simulants. This work will be carried out.during fiscal year 1996.

\section{Acknowledgments}

The following individuals were particularly helpful in the development of simulants and discussing technical details of the programs: at ORNL, T.E. Kent and W.D. Bond; at Hanford, J.G.H. Geeting, B.C. Bunker, and B.A. Reynolds. This work was done as part of the Office of Technology Development Tank Focus Area program (TTP \#SR1-4-20-11); C.P. McGinnis, Pretreatment Technical Integration Manager; D. Geiser, Office of Technology Development Program Manager.

\section{References}

$\checkmark$ 'D.J. McCabe, "Evaluation and Ranking of the Tank Focus Area Solid Liquid Separation

Needs (U)", WSRC-TR-95-0337, Revision 0, August 17, 1995.

$\sqrt{2}$ Personal communication with Bruce Reynolds, PNL.

${ }^{5}$ Personal communication with Tim Kent and Walt Bond, ORNL

Not "R. A. Peterson, C.A. Nash"Filter Performance Mechanisms", WSRC-TR-95-0420, October $c^{5}$ r. ReN 
Attachment 1. Hanford Simulant Preparation Instructions

\section{S-103}

\begin{tabular}{|l|l|l|}
\hline Component & Simulant 1-(0.05) & Simulant 2-(8.0) \\
\hline Initial Water & 3.6 liter & 3.6 liter \\
\hline $\mathrm{Fe}(\mathrm{NO} 3) 3 \cdot 9 \mathrm{H} 2 \mathrm{O}$ & $7.65 \mathrm{~g}$ & $1225 \mathrm{~g}$ \\
\hline $5 \mathrm{MNaOH}$ & $11.4 \mathrm{ml}$ & 1.82 liters \\
\hline Colloidal Silica & $4.05 \mathrm{~g}$ & $651 \mathrm{~g}$ \\
\hline Alumina (S-11) & $0.45 \mathrm{~g}$ & $70.6 \mathrm{~g}$ \\
\hline Boehmite alumina & $0.15 \mathrm{~g}$ & $21.7 \mathrm{~g}$ \\
\hline Calcium tri basic & $0.8 \mathrm{~g}$ & $130.3 \mathrm{~g}$ \\
\hline
\end{tabular}

Add iron nitrate to water and dissolve

Add $5 \mathrm{M} \mathrm{NaOH}$ slowly until $\mathrm{pH}$ is between 7.0 and 8.0. Stir for 30 minutes.

Add Silica, gibbsite, boehmite and calcium tri basic.

Add $5 \mathrm{M} \mathrm{NaOH}$ until $\mathrm{pH}$ is 12 . Stir over weekend.

Add $5 \mathrm{M}$ HNO3 until $\mathrm{pH}$ is 10 . Add water to bring final volume to 10 liters. Stir for 3 hours.

S-3

1. Add $40 \mathrm{~g} \mathrm{NaOH}$ to 5 liters of deionized water.

2. Add water to reach a volume of 10 liters.

3. add 785.8 grams of vista catapal D boehmite

4. add 174.6 grams of SpaceRite S-3, 1 micron gibbsite 
Attachment 2. NGLLLW Simulant Preparation Insructions

Add the following materials to 20 liters of water to prepare Solution 1 (NGLLLW).

\begin{tabular}{l|l|l|l}
\hline Component & Amount & Actual Added & Manufacturer/Lot \\
\hline $\mathrm{NaNO}_{3}$ & $101.7 \mathrm{~g}$ & & \\
\hline $\mathrm{NaCl}$ & $41.1 \mathrm{~g}$ & & \\
\hline $\mathrm{LiCl}$ & $21.2 \mathrm{~g}$ & & \\
\hline $\mathrm{NaAlO}$ & $19.2 \mathrm{~g}$ & & \\
\hline $\mathrm{NaOH}$ & $100 \mathrm{~g}$ & & \\
\hline $\mathrm{Na}_{2} \mathrm{CO}_{3} \cdot \mathrm{H}_{2} \mathrm{O}$ & 248.1 & & \\
\hline
\end{tabular}

Prepare Solution $2(10,000 \mathrm{ppm} \mathrm{Sr})$ add water to $0.242 \mathrm{~g} \mathrm{Sr}\left(\mathrm{NO}_{3}\right)_{2}$ to bring to $10 \mathrm{ml}$.

Prepare Solution $3(100,000 \mathrm{ppm} \mathrm{Sr})$ : add water to $2.42 \mathrm{~g} \mathrm{Sr}\left(\mathrm{NO}_{3}\right)_{2}$ to bring to $10 \mathrm{ml}$.

Prepare Solution $4(5 \% \mathrm{Fe})$ : add water to 4.4 grams of $\mathrm{Fe}_{2}\left(\mathrm{SO}_{4}\right)_{3} \cdot 9 \mathrm{H}_{2} \mathrm{O}$ to bring to $10 \mathrm{ml}$.

Prepare Solution 5 by adding $283 \mu \mathrm{L}$ of Solution 2 to Solution 1 .

Hold here.

While stirring vigorously $(1150 \mathrm{rpm})$ add solution 3 to solution 5 .

Add solution 4 to solution 5 then stir for 1 hour. 
Attacment 3. REDC simulant preparation instructions

Add the following materials to 2 liters of water to prepare Solution 1 (REDC).

\begin{tabular}{l|l|l|l}
\hline \multicolumn{1}{c|}{ Component } & Amount & Actual Added & Manufacturer/Lot \\
\hline $\mathrm{AlNO}_{3}$ & $480 \mathrm{~g}$ & & \\
\hline $\mathrm{FeNO}$ & $380 \mathrm{~g}$ & & \\
\hline $\mathrm{ZrONO}$ & $162 \mathrm{~g}$ & & \\
\hline $\mathrm{Sr}\left(\mathrm{NO}_{3}\right)_{2}$ & $0.217 \mathrm{~g}$ & & \\
\hline $\mathrm{Eu}\left(\mathrm{NO}_{3}\right)_{3} \cdot 5 \mathrm{H}_{2} \mathrm{O}$ & $0.282 \mathrm{~g}$ & & \\
\hline $\mathrm{Gd}\left(\mathrm{NO}_{3}\right)_{3} \cdot 6 \mathrm{H}_{2} \mathrm{O}$ & $0.287 \mathrm{~g}$ & & \\
\hline
\end{tabular}

Prepare Solution $2(2 \mathrm{M} \mathrm{NaOH})$ add $400 \mathrm{~g} \mathrm{NaOH}$ to water and bring to $5 \mathrm{~L}$, remove 1 liter and set aside.

Prepare Solution 3 by slowly adding solution 1 to 4 liters of solution 2 . Check $\mathrm{pH}$ of the solution. Adjust to $\mathrm{pH}$ of 7 with remaining liter of solution 2 (the amount of solution required should be small)

Allow solution to settle. Decant supernate. Record mass decanted.

Mass of vessel:

Mass of vessel + decant supernate:

Prepare solution Prepare Solution 4 by adding $40 \mathrm{~g}$ of $\mathrm{NaOH}$ to 10 liters of water.

Add solution 4 to solids to bring final volume to 10 liter.

Record final $\mathrm{pH}$ : 
Distribution:

S.D. Fink, 773-A

W.L. Tamosaitis, 773-A

R.A. Peterson, 676-T

B.W. Walker, 676-15T

C.A. Nash, 676-15T

J.N. Brooke, 719-4A

A.W. Wiggins, 241-152H

C.L. Leung, 241-119H

B.L. Lewis, 703-H

J.E. Marra, 704-56H

G.L. Cauthen, 241-119H

P.M. Patel, 704-26S

M.J. Plodinec, 773-43A

C.P. McGinnis, ORNL

M.G. Schwenker, 703-56A

N.F. Chapman, 704-99S

B.A. Reynolds, PNL

J.G. Geeting, PNL

T.D. Welch, ORNL

T.E. Kent, ORNL

W.D. Bond, ORNL

R.R. Brunson, ORNL

J.H. Wilson, ORNL

Tech. Info. Mgmt, 703-43A

IWT file (A. Patterson, 773-A) 